https://doi.org/10.5800/GT-2017-8-3-0267

\title{
PALEOARCHEAN MAFIC ROCKS OF THE SOUTHWESTERN SibERIAN CRATON: PRELIMINARY GEOCHRONOLOGY AND GEOCHEMICAL CHARACTERIZATION
}

\author{
A. V. Ivanov', I. V. Levitsky², V. I. Levitsky², E. I. Demonterova' ${ }^{1}$, L. Z. Reznitsky ${ }^{1}$ \\ ${ }^{1}$ Institute of the Earth's Crust, Siberian Branch of RAS, Irkutsk, Russia \\ ${ }^{2}$ A.P. Vinogradov Institute of Geochemistry, Siberian Branch of RAS, Irkutsk, Russia
}

For citation: Ivanov A.V., Levitsky I.V., Levitsky V.I., Demonterova E.I., Reznitsky L.Z., 2017. Paleoarchean mafic rocks of the Southwestern Siberian craton: preliminary geochronology and geochemical characterization. Geodynamics \& Tectonophysics 8 (3), 477-480. doi:10.5800/GT-2017-8-3-0267.

The Siberian craton consists of Archean blocks, which were welded up into the same large unit by ca 1.9 Ga [Gladkochub et al., 2006; Rojas-Agramonte et al., 2011]. The history of the constituent Archean blocks is mosaic because of limited number of outcrops, insufficient sampling coverage because of their location in remote regions and deep forest and difficulties with analytical studies of ancient rocks, which commonly underwent metamorphic modifications and secondary alterations. In this short note, we report data on discovery of unusual for Archean mafic rocks of ultimate fresh appearance. These rocks were discovered within southwestern Siberian craton in a region near a boun- dary between Kitoy granulites of the Sharyzhalgai highgrade metamorphic complex and Onot green-schist belt (Fig. 1). Here we present preliminary data on geochronology of these rocks and provide their geochemical characterization.

Methods. The rocks under consideration were discovered at two localities with size of about 500 by $500 \mathrm{~m}$ at a distance of about $3 \mathrm{~km}$ separated from each other at the middle stream of the Kitoy river. The rock occurrences are located at deep forest regions and geological relations with ambient rocks were not observed. According to regional tectonic subdivisions, the studied rocks are located within the Kitoy granulite block of 


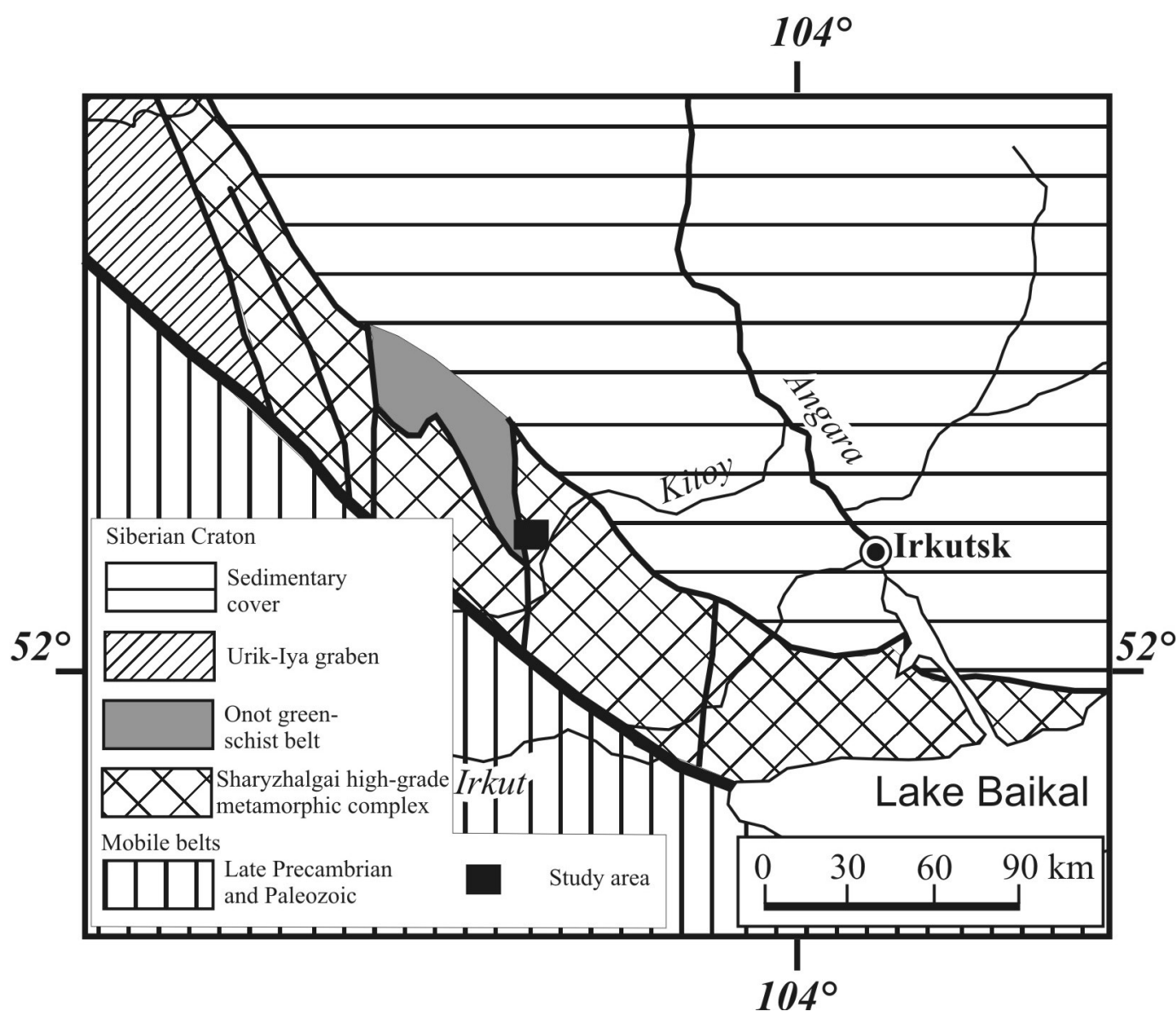

Fig. 1. Schematic map of the southern Siberian craton with the study area.

the Sharyzhalgai high-grade metamorphic complex. However, as will be discussed below, it cannot be ruled out that the ambient rocks belong to the Onot greenschist belt (Fig. 1).

The rocks initially were cut for thin sections to check them under the polarized microscope. It appeared that some of them retain original dolerite texture with fresh plagioclase-clinopyroxene-orthopyroxene-olivine mineral assemblage (Fig. 2). The rocks vary significantly, however, by the degree of secondary modification and metamorphism. Secondary minerals in dolerites are sericite, epidote, chlorite, zoisite and rarely biotite which constitute up to $5 \%$ in the most altered varieties. Metamorphic rocks are plagiogneisses and plagioschists with relics of original dolerite textures.

Having in mind extremely fresh-looking appearance of the minerals, seven dolerite samples were processed for K-Ar dating at the Centre of Geodynamics and Geochronology of the Institute of the Earth's Crust. Argon and potassium concentrations were measured using ARGUS VI mass-spectrometer and SOLAAR $M$ atomic absorption spectrometer, respectively. Prior the K-Ar dating, all samples were treated by $4 \mathrm{~N}^{-} \mathrm{HNO}_{3}$.

The same seven samples, though not treated by any acids, were used for major and trace element analyses, which were conducted at the Centre for isotope- geochemical studies of the A.P. Vinogradov Institute of Geochemistry and at the Centre of ultramicroanalysis of the Limnological Institute using S4 Pioneer XRF spectrometer and Agilent 7800 ICP-MS mass-spectrometer, respectively. $\mathrm{Nd}-\mathrm{Sm}$-isotopes were measured on

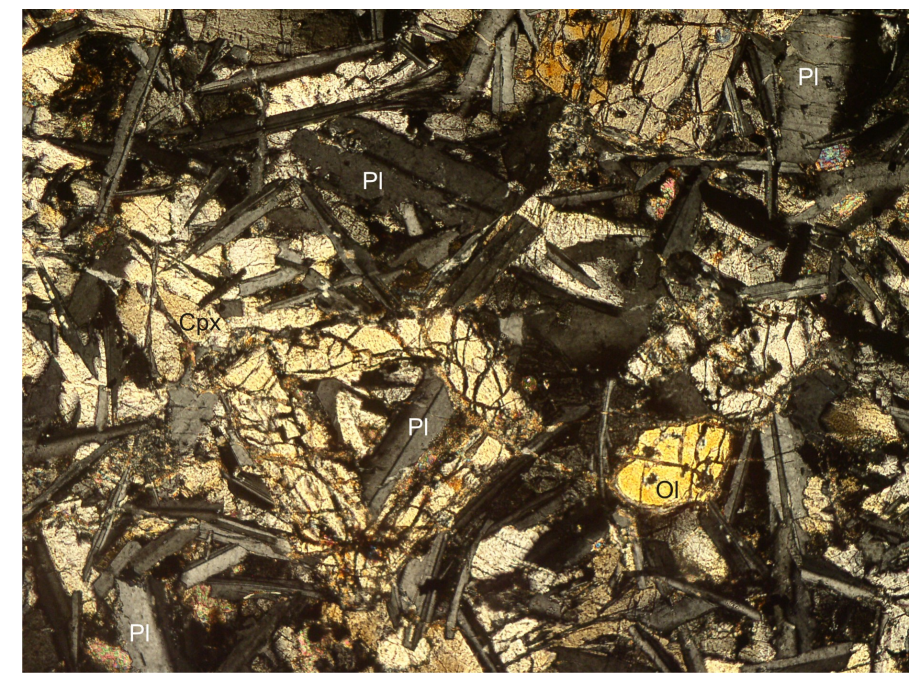

Fig. 2. Thin section of a sample dated at $3213 \pm 110$ Ma by $\mathrm{K}-\mathrm{Ar}$ method under a polarized microscope. Magnification is $10 \times . \mathrm{Ol}$ - olivine, $\mathrm{Cpx}$ - clinopyroxene, $\mathrm{Pl}$ - plagioclase. 


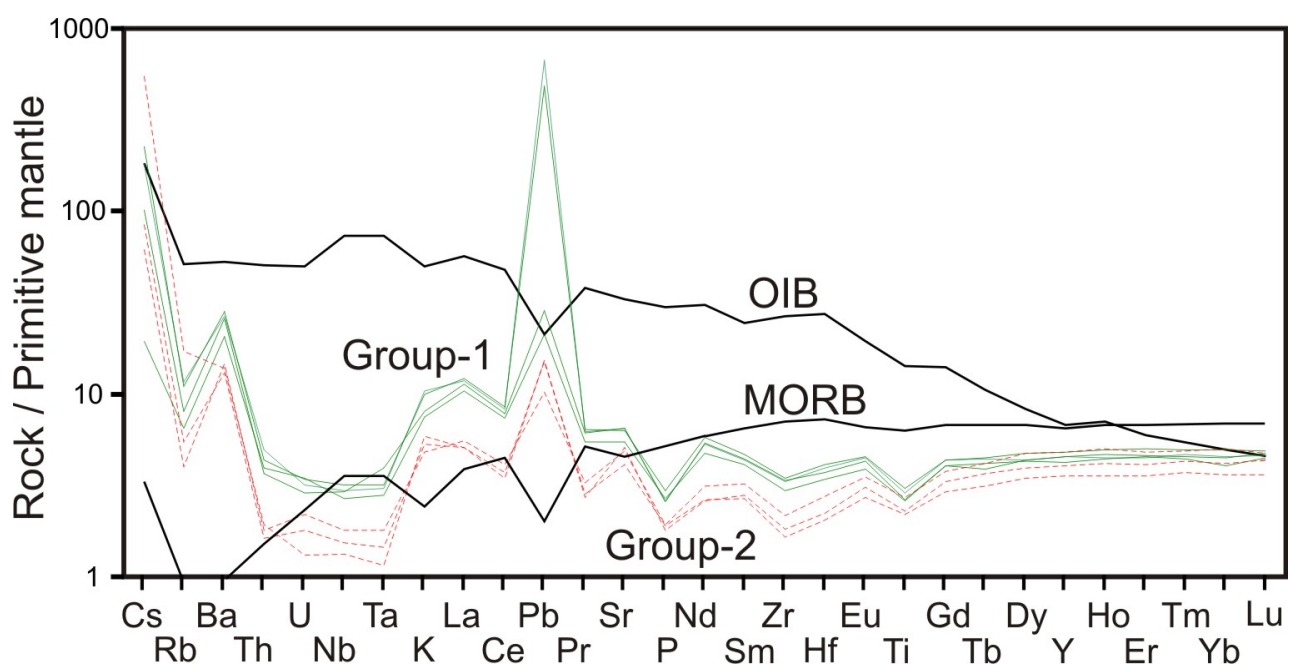

Fig. 3. Primitive-mantle [McDonough, Sun, 1995] normalized diagram for the studied samples. MORB and OIB reference lines are after [Sun, McDonough, 1989].

$2 \mathrm{~N} \mathrm{HCl}$-leached samples at the Centre of Geodynamics and Geochronology of the Institute of the Earth's Crust using Finnigan MAT262 mass-spectrometer.

Results. The performed K-Ar dating on seven dolerite samples has shown the range of ages between $1941 \pm 42$ and $3213 \pm 110 \mathrm{Ma}$. The youngest among the measured ages corresponds to a peak of granite magmatism and metamorphism in the southern Siberian Craton [Rojas-Agramonte et al., 2011]. The oldest of the measured ages is older than any published ages for the Sharyzhalgai high-grade metamorphic complex [Turkina et al., 2012] and approaching the oldest published age of $3386 \pm 14 \mathrm{Ma}$ for plagiogneisses of the Onot green-schist belt [Bibikova et al., 2006]. Thus we interpret the oldest of measured K-Ar ages as potentially yielding the true eruption age and the younger ages as due to complete or partial metamorphic resetting at ca $1.9 \mathrm{Ga}$.

The dolerites form two geochemical groups, referred to as group-1 and 2, which are identical by the heavy rare earth element (REE) concentrations at a level lower than in the modern mid ocean ridge basalts (MORB) but different by majority of the most incompatible elements, whose concentrations are intermediate between MORB and ocean island basalts (OIB) (Fig. 3). These two groups are different by their timecorrected (at $3.2 \mathrm{Ga}$ ) $\varepsilon \mathrm{Nd}$ values. The $\varepsilon \mathrm{Nd}$ values in group- 1 and 2 rocks vary between -2.6 and -4.7 and between -10.8 and -15.0 , respectively (Fig. 4).

Discussion. It seems that the studied rocks are quite unique among Archean rocks by their freshness, which allowed preserving the radiogenic argon. Most likely the oldest age $3213 \pm 110$ Ma obtained on one of the studied samples can be still younger than the true age of the rock because it is hard to believe that $100 \%$ of radiogenic argon in the sample is retained. In princi- ple, this age could be also too old in case of excess argon. Thus, the obtained K-Ar ages should be viewed as preliminary until confirmed through Ar-Ar dating and/or U-Pb dating, in case if zircon or baddeleyite are present. The additional problem in interpretation is related to difficulties in revealing geological situation, because no contacts with the basement rocks were observed because of deep forest.

Surprising are the geochemical features of the rocks as well. They show very low concentrations of the heavy REE, lower than in modern MORB, suggesting very high degree of partial melting ( $>15 \%)$. At the same time, they show high concentrations of some lithophile trace elements such as $\mathrm{Cs}, \mathrm{Rb}, \mathrm{Ba}$ and $\mathrm{Pb}$ (Fig. 3). Considering the freshness of the rocks, peaks of concentrations for these elements cannot be due to secondary alteration. This cannot be due to contamination of initial mantlederived melts by crustal material either, because the

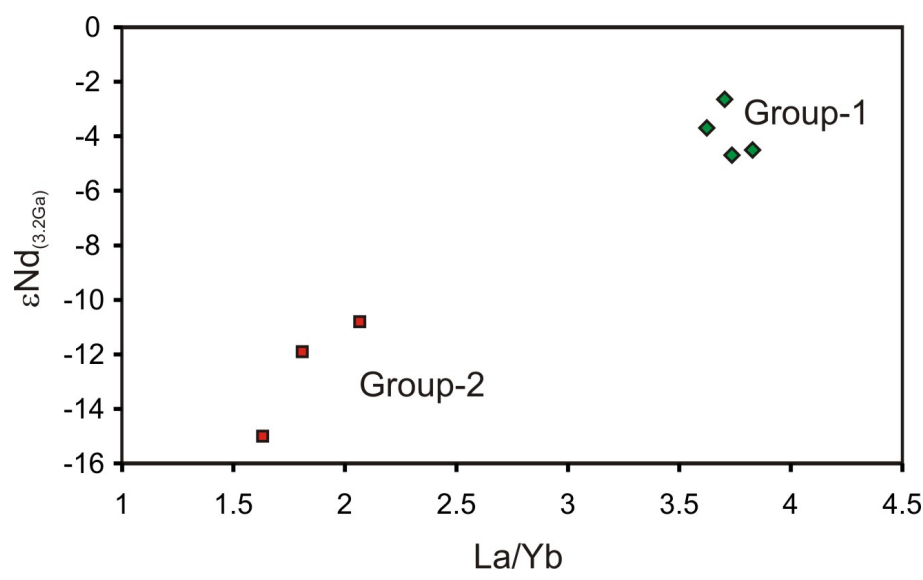

Fig. 4. Time-corrected (at $3.2 \mathrm{Ga}$ ) $\varepsilon N d$ relative $\mathrm{La} / \mathrm{Yb}$ in the studied rocks. 
group-1 rocks with the higher concentrations of these elements are characterized by higher $\varepsilon \mathrm{Nd}$ values compared to the group-2 rocks (Fig. 4). Thus, it seems, the only feasible explanation is recycling of crustal material at depth and melting of peridotite-crustal mixture at high degrees of partial melting.

Conclusion. Preliminary K-Ar dating of exceptionnally fresh dolerites discovered at the boundary between Sharyzhalgai metamorphic complex and Onot green-schists belt suggests that these rocks are among the most ancient rocks of the Siberian craton.
These dolerites have unusual geochemical features, combining very low concentrations of the heavy REE and high concentrations of some lithophile elements such as $\mathrm{Cs}, \mathrm{Rb}, \mathrm{Ba}$ and $\mathrm{Pb}$.

$\mathrm{Nd}$-isotope data suggest that the source of melting at 3.2 Ga already contained highly evolved crustal material.

Acknowledgements. Analytical work for this study was supported by the Russian Science Foundation, grant 16-17-10068.

\section{REFERENCES}

Bibikova E.V., Turkina O.M., Kirnozova T.I., Fugzan M.M., 2006. Ancient plagiogenisses of the Onot block of the Sharyzhalgai metamorphic massif: isotopic geochronology. Geochemistry International 44 (3), 310-315. https:// doi.org/10.1134/S0016702906030098.

Gladkochub D.P., Pisarevsky S.A., Donskaya T.V., Natapov L.M., Mazukabzov A.M., Stanevich A.M., Sklyarov E.V., 2006. The Siberian craton and its evolution in terms of the Rodinia hypothesis. Episodes 29 (3), 169-174.

McDonough W.F., Sun S.-S., 1995. The composition of the Earth. Chemical Geology 120 (3-4), 223-253. https://doi.org/ 10.1016/0009-2541(94)00140-4.

Rojas-Agramonte Y., Kröner A., Demoux A., Xia X., Wang W., Donskaya T., Liu D., Sun M., 2011. Detrital and xenocrystic zircon ages from Neoproterozoic to Palaeozoic arc terranes of Mongolia: Significance for the origin of crustal fragments in the Central Asian Orogenic Belt. Gondwana Research 19 (3), 751-763. https://doi.org/10.1016/j.gr. 2010.10.004.

Sun S.-S., McDonough W.F., 1989. Chemical and isotopic systematics of oceanic basalts: Implications for mantle composition and process. In: A.D. Saunders, M.J. Norry (Eds.), Magmatism in the oceanic basins. Geological Society, London, Special Publications, vol. 42, p. 313-345. https://doi.org/10.1144/GSL.SP.1989.042.01.19.

Turkina O.M., Berezhnaya N.G., Lepekhina E.N., Kapitonov I.N., 2012. U-Pb (SHRIMP II), Lu-Hf isotope and trace element geochemistry of zircons from high-grade metamorphic rocks of the Irkut terrane, Sharyzhalgay uplift: Implication for the NeoArchaean evolution of the Siberian craton. Gondwana Research 21 (4), 801-817. https://doi.org/ 10.1016/j.gr.2011.09.012. 